\title{
Boko Haram and Nigeria's National Security: Some Reflections from Historical-Constitutional Perspective
}

\author{
Prof. Kaniye S. A. Ebeku \\ LLB (UST), LLM (LSE, London), PhD (Kent, UK) \\ Pioneer Dean of Law, University of Port Harcourt, \\ Honourable Commissioner for Education, Rivers State, Nigeria
}

\begin{abstract}
Acts of terrorism perpetrated by Boko Haram have been a serious national security concern in Nigeria since 2009 . Since then, the terrorist organization has executed several acts of terrorism in different parts of Nigeria, particularly in the northern states. Noteworthy, some of the acts of terrorism have been targeted against Churches and Christians. Ideologically, it is well-known that Boko Haram detests western civilization and education, and abhors Christianity; its avowed motive is to Islamize Nigeria, contrary to the secular status of Nigeria enacted in the Constitution of Nigeria 1999 (as amended). From historical perspective, the struggle to Islamize Nigeria can be traced way back to the colonial era when Nigeria was under British rule and subsequently from the first republic. Under the 1999 Constitution, Sharia has a limited application and the Constitution is supreme. On the contrary, Boko Haram wants Sharia to be the supreme law of the land, and this informs its terrorist campaigns. Under Nigerian law, acts of terrorism are forbidden. However, this article argues that the law and the judiciary have not, so far, been helpful in checking the terrorist activities of Boko Haram.
\end{abstract}

Keyword: Boko Haram, National security in Nigeria, Terrorism in Nigeria, Islamization of Nigeria, Secularism in Nigeria

\section{INTRODUCTION}

'No man is an island, entire of itself; every man is a piece of the continent, a part of the main. If a clod be washed away by the sea, Europe [Nigeria] is the less, as well as if a promontory were, as well as if a manor of thy friend's or of thine own were: any man's death diminishes me, because I am involved in mankind, and therefore never send to know for whom the bells tolls; it tolls for thee.'(Underling supplied)

- Devotions Upon Emergent Occasions, 'Meditation XVII' (John Donne)

'... Boko Haram threatens the future of our country.'

- State Security Service 
Ebeku, K. S. A. (2020). Boko Haram and Nigeria's National Security: Some Reflections from Historical-Constitutional Perspective. Advances in Social Sciences Research Journal, 7(5). 503-521.

Without a shadow of doubt, these are trying times in Nigeria. From the North-Eastern part of Nigeria especially as well as other parts of Northern Nigeria we hear daily tales of unmitigated acts of terrorism: chilling, blood-letting escapades of an Islamic sect called 'Boko Haram'.1 As we have seen from the recent incidents at Nyanya, even the federal capital territory Abuja is not spared. Then there was the recent bombing in Jos, Plateau state, and the unmitigated act of wickedness of dramatically kidnapping over 200 high school girls from their hostel in Chibok, Borno state in April 2014. Yet the sect is not done. In fact, the tale of woes and killings in recent times in Nigeria reminds one of the daily savageries in Iraq perpetrated by suicide bombers, especially between 2003 and $2010{ }^{2}$ While no official statistics exists on the number of attacks by the organization as at May 2014, it has been found that 'as of May 2012 there have been well over 160 separate attacks reckoning from July 2009 when the first attack was launched. ${ }^{3}$ What is more, 'since January 2012 the attacks occur virtually daily; thus putting Nigeria on the international spotlight for the wrong reasons: the new hot-spot of terrorism in the world. ${ }^{4}$

Sadly, the Nigerian Armed forces, even with foreign military assistance, have not yet been able to contain the terrorist acts of Boko Haram. In fact, daily attacks have not abated since 2012. This implies that insecurity reigns in Nigeria at the moment. So, one may ask, has the federal government failed in its primary responsibility to the people of the country -i.e. security of lives and property? Some have answered in the affirmative. This may well be so. However is it not pedestrian to suggest this without interrogating the motives of those behind the dastardly acts as well as the political and constitutional milieu? This paper examines the origin and possible motives of the terrorists and discusses the religious and political angles of the insurgency from a historical and constitutional perspective. Furthermore, it will briefly consider the legal framework for the prevention of terrorism in the country in order to assess the role of the law in the fight against terrorism. The paper will end with some concluding remarks.

\section{Origin and Motives of Boko Haram}

The Nigerian Islamic sect popularly known as Boko Haram was probably established in 2002 in the city of Maiduguri. ${ }^{5}$ The official Arabic name of the organization is Jama'atu Ahlis Sunna Lidda'awati Wal-Jihad - which translates in English as People Committed to the Propagation of the Prophet's Teachings and Jihad. ${ }^{6}$ The term 'Boko Haram' is a combination of Hausa and Arabic languages respectively and literally translates as 'Western education is forbidden' or 'Western education is sinful'. ${ }^{7}$ The sect ${ }^{8}$ earned this epithet from the local residents of Maiduguri because of its avowed hatred for Western education which it sees as corrupting Muslims and therefore 'sinful'. ${ }^{9}$ According to some of its public comments, the sect is fighting to end Nigeria's secular Constitution and establish an Islamic state based on Sharia ${ }^{10}$ - a body of Muslim religious law as revealed by God. According to one source, members of the group are influenced by the Koranic ${ }^{11}$ verse which states that 'anyone who is not governed by what Allah has revealed is among the transgressors'.11

Some sources suggest that the sect started off in 2002 as a purely religious and harmless body. ${ }^{12}$ Its founder, Mohammed Yusuf, established a religious complex which housed a Mosque and an Islamic school and many Muslim families within and outside Nigeria (particularly, from neighbouring countries such as Chad and Niger republic) enrolled their children at the school. ${ }^{13}$ After seven years of operations, it seems security operatives suspected that the organization was arming itself and recruiting fighters to wage a religious war in the country and swiftly attacked the organization, killing its founder and leader Mohammed Yusuf in controversial circumstances..$^{14}$ According to some 
analysts, the retaliatory attack of the sect in 2009 inaugurated the current terrorism dimension of the organization. ${ }^{15}$

Now, if the Boko Haram attacks of 2009 were retaliatory one may ask why they are continuing since then in a manner that clearly demonstrates terrorism. Some observers have suggested that the underlying motive is the drive to Islamize Nigeria. However, there are those who dispute the religious motive and suggest that the terrorist acts are the result of widespread poverty in the country, especially in the north-eastern part of the country where the attacks are basically concentrated. They believe that reducing unemployment will help to end the insurgency. Still some believe that politics or the struggle for high political offices in Nigeria is behind the terrorist acts of Boko Haram. Mark Anikpo is one of those who believe that politics is the central motive of those behind the terrorist acts. In a recent interview with the Uniport Weekly he expressed his position thus:

I do not buy the idea that the reason for the insurgence is...poverty. In many Nigerian villages people are poor and they have not taken up arms to kill people. The most obvious reason is the political motive behind it. This is because one begins to wonder the link between the upsurge in insecurity and the 2015 general elections... [I]t is curious that as we get closer to the elections, the insurgency is increasing...16

The same view was also recently expressed by Labaran Maku, Nigeria's Minister of information, on a Radio Nigeria Phone-in Programme reported on the 7 O'clock network news of Radio Nigeria on 1 June 2014. While urging Nigerians to rise above party affiliation in the fight against terrorism he observed that some politicians have turned the insurgency into a political opportunity for 2015; 'they think that the more the bombs are exploded the more they will come to power in 2015'. Surely, as adumbrated below, it is difficult to deny the link between the 2015 scheduled elections and the increasing acts of terrorism in the country.

Furthermore, emphasizing the political motive of the insurgency Anikpo further dismissed the religious angle in the following words.

To say that the problem is religious is ridiculous, because the most recent occurrence is [sic] not only on Churches. Moslems, Christians and everybody are being killed. The implication of what is happening is that the capture of political power is the root of it all. If the situation continues, it will lead to loss of confidence by the people in the present administration. It may also lead to more violence or even the desire by the electorates to change the government in the next elections. ${ }^{17}$

While I agree that poverty per se is not a key reason for the terrorist acts of Boko Haram, I suggest that it is idle to think that acute poverty and unemployment plays no role in the insurgency. In fact, Anikpo recognizes the role of poverty in helping the cause of the insurgency by recommending the reduction of unemployment and the implementation of social security scheme by which 'the unemployed would be entitled to some welfare package, no matter how small'.18

However, with due respect to Anikpo - a respectable Professor of Sociology - I am not persuaded by his assertion that the suggestion of religious motive is 'ridiculous' because of the reason advanced by him. On the contrary, a study of earlier attacks as outlined below has shown that they 
Ebeku, K. S. A. (2020). Boko Haram and Nigeria's National Security: Some Reflections from Historical-Constitutional Perspective. Advances in Social Sciences Research Journal, 7(5). 503-521.

were targeted at Christians. Moreover, some public statements of the sect clearly disclose their religious motive, i.e. the Islamization of Nigeria or the struggle for the supremacy of Sharia law in Nigeria, and this can be regarded as an aspect of the political motive. Hence, the political motive which he emphasizes can be said to be intertwined with the religious motive. This is the position taken in this paper.

\section{Boko Haram, Nigerian National Security and Religious/Political Struggle}

Many observers of Boko Haram insurgency in Nigeria have claimed that despite its peaceful beginnings the ultimate political goal of the Islamic organization is the overthrow of the Nigerian government as presently constituted under a secular Constitution and the establishment of an Islamic state with Sharia replacing the Constitution as the supreme law of the land..$^{20}$ This may be described as a religious-political objective. As already seen above, there is yet another political aspect, which is the seeming plan of some Nigerian politicians to ride to political power in 2015 on the back of Boko Haram terrorism. This is a latter day political motive which does not necessarily displace the original religious-political motive of the sect. As will be observed below, the pursuit of any aspect of the political goal through acts of terrorism produces national insecurity.

Regarding the religious-political aspect, the utterances and escalating acts of the organization lend credence to the suggested goal. A few examples taken from the limited statements ${ }^{21}$ and actions of the organization will suffice to illustrate this point. Before this, let me caution that the authenticity of the 'Boko Haram materials' used here has not been independently verified. I rely on them here only because the organization has not repudiated them as they would normally do.

Firstly, in a video recording posted on YouTube by the sect in January 2012, Imam Abubakar Shekau -the acclaimed leader of the sect ${ }^{22}$ - explained the rationale for the terrorist attacks of the organization as follows:

We hardly touch anybody except security personnel and Christians and those [Muslims] who have betrayed us. Everyone knows what Christians did to Muslims, not once or twice. Why I have come out to explain myself is because of the explanation Jonathan and the Christian Association of Nigeria (CAN) President gave on us, including the various versions people give about us that we are like cancer (a terrible ailment) in this country called Nigeria. No, we're not cancer, neither are we evil. If people don't know us, God knows everyone. Everyone knows what happened to our leader. Everyone knows what wickedness was meted out to our members and fellow Muslims in Nigeria from time to time... Everyone knows that democracy and the constitution is paganism and everyone knows there are some things that God has forbidden in the Quran that cannot be counted even western education! We have stopped everything apart from saying we should stay on the path of truth and peace and live right in the sight of God. There, we will have peace and that is what we have been preaching and because of that they said we should be killed and our mosques destroyed. We decided to defend ourselves and God has said if you follow him, he will give you strength!23 (Emphasis added)

From the foregoing, it is clear, inter alia, that the sect seeks to end democracy in Nigeria together with the secular Constitution of the country and in their place enthrone a theocratic government under Islamic law. 
Secondly, other portions of the same statement further provide evidence of the political intention of the sect. For example, the sect wants to see Islam as the religion of the Nigerian State contrary to the provision presently contained in Section 10 of the 1999 Constitution of Nigeria. An indication of this is the demand of the sect that President Jonathan and other Christians (including the President of the Christian Association of Nigeria (CAN)) should convert to Islam. Moreover, the sect urges Christians to 'know that Jesus is a servant and prophet of God' and 'not the son of God'24 as the Bible - the Holy Book of Christians - teaches. Furthermore, they maintain that Christianity 'is not a religion of God - it is paganism' and pointedly declared that they are fighting to coerce Christians to 'embrace Islam, because that is what God instructed us to do'.25

In furtherance of its objective of Islamizing Nigeria, the sect has executed some targeted attacks on Christians. For present purposes, a few instances will suffice to illustrate this point. Firstly, on 25 December 2011 (Christmas-Day), the organization executed coordinated attacks on Churches at different locations in Nigeria, including an attack at St. Theresa's Catholic Church, Madalla, at the outskirts of Nigeria's Federal Capital Territory Abuja ${ }^{26}$ an attack on Mountain of Fire and Miracles Church in the central city of Jos, Plateau State; and an attack at a Church in Gadaka in Yobe state in northern Nigeria. ${ }^{27}$ Similar attacks occurred in Jos on Christmas Eve 2010.28

Furthermore, between January and April 2012 similar attacks were executed ${ }^{29}$ For instance, an attack at a Deeper Life Bible Church in Gombe state on 5 January $2012^{30}$ an attack at Christ Apostolic Church in Adamawa state on 9 January 2012;31 and an attack on 8 April 2012 (Easter Sunday) in Kaduna state targeted at a group of three Churches located side by side. ${ }^{32}$ According to human rights groups, various Boko Haram attacks since July 2009 have caused the loss of over 1000 lives as of May 2012.33

Further evidence of the religious-political intention of the sect may be found in a leaflet distributed around the city of Kano overnight after the city suffered a deadly attack on 20 January 2012. In it, the sect vowed to continue its struggle to 'install an Islamic system'34 in Nigeria. The sect noted 'the atmosphere of inconvenience our operations have thrown people into ${ }^{35}$ ' but urged that people should 'persevere with the difficult situation the struggle for the entrenchment of an Islamic system puts you in and seek reward from God by supporting it'. ${ }^{36}$

In summary, the foregoing indicates systematic religious cleansing. ${ }^{37}$ Put in other words, the actions indicate a determined pursuit of the sect's avowed objective of wiping out Christianity in Nigeria and implementing Sharia in the country - at least in the northern parts of the country where historically there is a predominance of Muslims. This thinking is further encouraged by the ultimatum issued by the organization to all Christians in the northern parts of Nigeria to leave the Muslim north. ${ }^{38}$

It is important to note that prevailing Boko Haram attacks and the national insecurity and tension they create have long been foretold by Islamic scholars and clerics. The central issue is the place of Sharia in the Nigerian Constitution. It is clear that the compromise position on Sharia as presently contained in the 1999 Constitution of Nigeria (the 1979 Constitution before it) is not acceptable to some Muslims (including the terrorists now operating as Boko Haram). A few statements of Islamic scholars and clerics will illustrate this point, but for present purposes the statements of Sulaiman will suffice. ${ }^{39}$ 
Ebeku, K. S. A. (2020). Boko Haram and Nigeria's National Security: Some Reflections from Historical-Constitutional Perspective. Advances in Social Sciences Research Journal, 7(5). 503-521.

For example, Sulaiman has argued that 'the Shariah... deserves more than what is given to it in the Constitution ${ }^{40}$ and predicted that 'continuous prevention of its full application will eventually be a source of tension and conflict in Nigeria'. ${ }^{41}$ For him and many Muslims, Sharia is 'certainly a legitimate - a most legitimate - law in Nigeria and it is indeed the only one that will answer our needs and solve our multiple problems'. ${ }^{42}$ Notably, in addition to his statement earlier reproduced above, he further writes: 'To believe that the sentences of the Constitution can drive Islam to the background is a mere adventure in aberrations. Islam is too powerful to submit, forever, to earthly forces...' ${ }^{43} \mathrm{He}$ further stated what appears to be the philosophy which seems to be the driving force of Boko Haram:

[T] he only way that a Muslim can show his sincerity in his belief in Allah and in Mohammed, is to struggle, wherever he is, for the supremacy of the Shariah, to the point of sacrificing his dear life. Death in the struggle for the Shariah is the supreme achievement for which every Muslim aspires. It is the greatest service one can ever render to Allah, and, therefore, to humanity. ${ }^{44}$

In fact, it is possible to argue that Sulaiman's writings are a great source of inspiration for Boko Haram. For instance, Boko Haram's avowed hatred for Western education appears to have been influenced by his opinion: ${ }^{45}$

We have a duty to change our system of [Western] education and the Universities should be reminded that at present they are not producing useful and relevant people for the society, but destructive and debasing elements who lack originality and sense of purpose to make any meaningful contribution to the moral and material advancement of our society. ${ }^{46}$

To-date, there is no evidence from any source that Nigerian Muslims have repudiated the above words of Sulaiman since the 1980s when they were written. Importantly, although northern Nigeria political elite openly condemn Boko Haram's acts of terrorism which result in the loss of lives and property it is arguable, indeed it has been suggested, ${ }^{47}$ that the condemnations fall short of clear repudiation of the organization's open and avowed challenge to the present constitutional status of Sharia under the 1999 Constitution of Nigeria and their objective of Islamising Nigeria. For example, the Sultan of Sokoto - the Muslim religious leader of Nigeria - merely condemns the terrorist acts of the organization and has not consistently, specifically and unequivocally rejected its declared objective $^{48}$ of Islamizing Nigeria. In one forum in April 2014 he declared: 'Nobody can Islamise Nigeria, if Allah wanted he would have made everybody Muslims, so also with Christianity. God would have made everybody Christian if He wanted'. He further pointedly stated that 'the activities of the insurgents [Boko Haram] should not be seen as an attempt by Muslims to prosecute Christians or turn Nigeria into an Islamic country'. In contrast, he stated more recently:

The [Nigerian] Muslims feel rightly so marginalised, the Muslims feel not being treated equally as equals in this country. Therefore, the Muslims want and also demand being treated with equality, justice and fairness and In Sha Allah, things will turn around and be better for our country... We are ready any time to offer concrete advice, purely based on Islamic injunctions and tenets to our leaders. When we do so, we have discharged our responsibility as ordered by Allah. The rest is left for the political leaders to do what is right... ${ }^{49}$ 
One may ask, if there is no plan to Islamize Nigeria why his advice to governments must be restricted to 'purely Islamic injunctions and tenets'. The only logical conclusion is that advice derived from other sources, such as Christian sources, are inferior or not wanted. In effect, it is arguable that the Muslim leadership in Nigeria as well as many Nigerian Muslims agree in principle with the ultimate objective of Boko Haram, but maybe not with its tactics of terrorism. Viewed this way, the national question examined below is clearly engaged.

Significantly, unlike the previous attacks outlined above, more recent attacks have tended to be indiscriminate as Christians and Moslems alike are killed with reckless abandon. This is the case with the recent bombings in Nyanya and Jos and also the kidnapping of over 200 girls from their school in Borno state. This may be explained as a change in tactics, most likely aimed at creating general insecurity in the country for political purposes but does not necessarily mean the abandonment of the original religious-political motive behind the insurgency. In fact, the sect has explained that some of the kidnapped girls have converted to Islam.

There is no question that opposition politicians are politicizing the recent upsurge in insecurity in the country generated by daring and increasing Boko Haram attacks. Their utterances, statements and actions strongly suggest that they are making a political capital of the insecurity, and it may be difficult to deny a suggestion that they are fuelling the insurgency. As earlier mentioned, this is the position taken by some observers of the prevailing insecurity situation in Nigeria. What is not certain yet is the exact role that individual politicians or opposition parties are playing in furthering the terrorism. This is what security/intelligence operatives are working on.

Meanwhile one may ask how we got to this insecurity situation. Perhaps a little foray into Nigerian constitutional history may provide some clue.

\section{BACKGROUND TO THE INSECURITY SITUATION IN NIGERIA}

The prevailing insecurity in Nigeria did not arise over night; it has its roots in history. It is platitudinous to point out that Nigeria was a British creation. As Hatch has noted a long time ago, "no such entity as "Nigeria" existed until 1914. It was the creation of the British government...The peoples who inhabited the region now known as Nigeria had always lived in separate and often contentious societies'. ${ }^{50}$ More importantly for present purposes, he points out that:

[W] hen, late in the nineteenth century, the British claimed suzerainty over those lands which now comprise Nigeria, they were not annexing a "country", a "nation" or a "state". Britain negotiated with the French and Germans certain colonial frontiers; within this area lived many different societies, speaking no common language, following no common religion, and sharing no common culture. Britain imposed her authority over them, creating certain administrative institutions to exact that authority. In 1914 all these varied societies were declared by Britain to be members of a single state named Nigeria. ${ }^{51}$ (Emphasis added)

From authoritative historical records, at the time the British colonizers arrived the area now called Nigeria they met an established system of government in the northern part which was based on Islamic law and a majority of the people who were Muslims, while in the southern part of the area the people followed various traditional religions and the systems of government was based on various customary laws. ${ }^{52}$ The colonizers introduced their Christian religion to the colonized people 
Ebeku, K. S. A. (2020). Boko Haram and Nigeria's National Security: Some Reflections from Historical-Constitutional Perspective. Advances in Social Sciences Research Journal, 7(5). 503-521.

and this was widely embraced in southern Nigeria. Thus, by the time the southern and northern Nigeria were amalgamated in 1914 Christianity and Islam were the two main religions in the southern and northern Nigeria respectively. It is indisputable that the various peoples were not consulted nor was their consent sought and obtained before the British amalgamated the northern and southern Nigeria in 1914. Herein lies the seed of the controversial question of the place of Islamic law in Nigerian constitutionalism which was to emerge after the country's independence in 1960.

Essentially, the question of the constitutional status of Sharia has two aspects. Firstly, whether in a united Nigeria Sharia should form the basis of the national Constitution; and, secondly, whether in the alternative and as a minimum Nigerian Muslims should be allowed to practice all aspects of Sharia (civil as well as criminal). As against the position of anti-Islamism elements in Nigeria, the pro-Sharia elements in Nigeria (most Nigerian Muslims) insist on making Sharia the supreme law of Nigeria and the source of all laws of the land. As an irreducible minimum, they would want a Nigerian Constitution which allows Muslims to practice and be bound by all aspects of Sharia wherever they may be in Nigeria. Where either situation exists, Sharia is effectively the national constitution.

Ahmadu Bello (first Premier of Northern Nigeria) was one of the earliest proponents of Islamization of Nigeria. In an article published in a magazine called Jihād Manuscripts on 25 July 1962 he stated, inter alia:

Muslim Law is a law written in clear terms. It has stood the test of time. It cannot be worked out in Nigeria. The judges of the High Courts are learned men in their own fields. But their learning is incomplete in the eyes of the Muslims. The amendment to the Constitution of Northern Nigeria was made by my Government purposely to enable the learned Judges to obtain the expert advice of the Grand Khadi of the Sharia Court of Appeal who is also versed in his own field - when hearing a case involving Muslim personal law... Is it an attempt to suppress and eventually exterminate Muslim Law in the legal system of the Federation [of Nigeria]? When the time comes I will mobilize the people of the Region [Northern Nigeria] so that they can play their full part in this allimportant task which might be likened to a Jihad... A Jihad is war waged for some sacred interest to protect the faith, life, property, liberty and self-respect. ${ }^{22}$ (Emphasis added)

Two years later, in his address to the World Moslem League in November 1964 in Medina, he confidently asserted that 'when we clean Nigeria [of non-Muslims] we will go further afield in Africa'. ${ }^{53}$ It is important to note that at that early time, the issue of Islamization of Nigeria did not cause any national controversy; the statements were simply ignored. But should they have been so ignored?

In support of their position, pro-Sharia elements point out that Sharia provides a complete code which a true Muslim is bound to respect and practice. In the words of Alhaji Yahya Gusau, 'Shariah means everything to the Muslim...we [Nigerian Muslims] cannot lay claim to being Muslims if we cease believing in the Shariah. ${ }^{54}$ In other words, pro-Sharia elements reject the limited applicability of Sharia under the current Nigerian Constitution. ${ }^{55}$ 
On the contrary, the opponents of Islamism in Nigeria argue that in the interest of unity, peaceful and harmonious co-existence a united, multi-ethnic and multi-religious Nigeria should remain secular as the British colonizers who created the country designed it to be. Rotimi Williams summarized this position well in the following words: 55

Some of the commentators [on the 'Sharia Question'] have said that we have not gone far enough in ensuring the development of Islamic law. ${ }^{56}$ I suspect that those who say this are not prepared to make the type of compromises which are essential to the formulation of a federal constitution and indeed the survival of Nigeria as a united country. During the debate in the Constitution Drafting Committee, the attention of members was drawn to the fact that Islamic law provides a system of jurisprudence capable of dealing with all types of justiciable matters in modern society...But it must be remembered that Nigeria is a secular State and whilst the nation should be prepared to accommodate all religious faiths it ought not to do anything which is calculated to impose a system of laws associated with a particular religion upon people who do not believe or practice the faith which is the basis of that religion. Moreover, there must be give and take in our efforts to establish a stable federation in which all of us wish to live as brothers irrespective of our religious beliefs', 57

Undoubtedly, the 'Sharia Question' is a constitutional question par excellence in Nigeria. Support for this can be found in the words of Sulaiman - a leading Nigerian Muslim scholar - countering the case for secularism in Nigeria. For him, 'it is a fact that Islam is directly opposed to secularism, for secularism has no relevance to Islam'. ${ }^{58} \mathrm{He}$ argues that the 'secular argument' is 'perhaps the most deceitful argument that can ever be advanced when discussing a matter as the future of this country [Nigeria]'. ${ }^{59}$ He points out that 'secularism' is a Euro-Christian concept 'imposed on the country [by British colonizers], to the exclusion of the rest of the systems including Islam' ${ }^{60}$ Furthermore, he argues that to accept 'secularism' without question is 'to accept colonialism as a valid and legitimate and justifiable imposition' on the pre-colonial peoples of Nigeria and also to say that its 'institutions and legacy' should be accepted 'almost unconditionally'. ${ }^{61}$ Clearly, for him, this is unacceptable and Nigerians must arrange their country having regard to their pre-colonial history. Thus the place of Islam in Nigeria has become a national question.

\section{The National Question: Constitutionalism versus Islamism}

"The [Nigerian] Muslims feel rightly so marginalised, the Muslims feel not being treated equally as equals in this country. Therefore, the Muslims want and also demand being treated with equality, justice and fairness and In Sha Allah, things will turn around and be better for our country... We are not happy with the situation in terms of development in this country. We are ready any time to offer concrete advice, purely based on Islamic injunctions and tenets to our leaders. When we do so, we have discharged our responsibility as ordered by Allah. The rest is left for the political leaders to do what is right... We are gathered here to reflect on the mood of Muslims of this nation, and we are assuring Mr President that we are committed to peace and stability, ready to help him and government at all levels to bring peace... Whatever we can do as long as it is not against Islam, we are ready to do it 100 per cent."64 (Emphases added)

- The Sultan of Sokoto and President-General of the Nigerian Supreme Council for Islamic Affairs (NSCIA), Alhaji Sa'ad Abubakar III (The Nation, 26/05/2014). 
Ebeku, K. S. A. (2020). Boko Haram and Nigeria's National Security: Some Reflections from Historical-Constitutional Perspective. Advances in Social Sciences Research Journal, 7(5). 503-521.

The current Constitution of Nigeria is the Constitution of the Federal Republic of Nigeria 1999, the provisions of which are almost on all fours with the former Constitution of 197965 Unlike the case in other federations the world over, ${ }^{66}$ this single constitutional charter governs the constitutional affairs of the federal government as well as those of the 36 constituent states of the federation of Nigeria. ${ }^{67}$ This section provides only a summary of the relation of Islamic law to the Nigerian Constitution. This is important because this critical issue is at the centre of prevailing Boko Haram insurgency in the country.

As a point of departure, it should be noted that Nigeria is a country of about 160 million people with Christianity and Islam as the dominant religions. ${ }^{68}$ While many Muslims contend that Nigeria is a Muslim majority country ${ }^{69}$ there is as yet no reliable and verifiable evidence to prove this and it would seem that the contrary is indeed the case. ${ }^{70}$ More importantly, as has already been shown, the question of the constitutional status of Sharia has been a recurring discourse in Nigeria since the 1970s. The central issue may be described as a contest between constitutionalism and Islamism. Constitutionalism ${ }^{71}$ here refers to a situation where the constitution is secular and supreme; superior to any other laws of the land, religious or otherwise. On the contrary, Islamism refers to a situation where Islamic laws and principles are superior to any other laws, including the constitution. In other words, Islamic law is the ultimate law of the land, as is the case in some Islamic states. For example, Chapter 1, Article 3 of the Afghan Constitution of $2004^{72}$ provides that in Afghanistan, no law shall contravene the tenets and provisions of the holy religion of Islam'. To be sure, this provision is a core value or basic article of the Constitution which is not amenable to amendment. ${ }^{73}$

As has already been indicated, while Nigerian Christians prefer constitutionalism many Muslims insist on Islamism - thus raising the issue of the constitutional status of Sharia. This issue was first robustly debated in the 1970s during the processes of making the 1979 Constitution of Nigeria. A compromise position reached at that time was incorporated into the 1979 Constitution ${ }^{74}$ and retained in the current Constitution of 1999. Essentially, the Constitution is supreme over all other laws of the land, including Islamic laws and customary laws. ${ }^{75}$ Furthermore, the Constitution forbids adoption of any religion as a state religion. ${ }^{76}$ However, it allows a limited application of Islamic laws (Sharia; also spelt 'Sharī'ah') in Nigeria: essentially, that Sharia may be applicable in states where it may be deemed necessary, but only in the area of personal law, and that Sharia Courts including appeals instances may be established by any state of the Nigerian federation that needs them ${ }^{77}$ to administer the Muslim personal law.78 Importantly, the criminal aspects of Sharia have no application under the Constitution. In summary, the Nigerian Constitution is secular and supreme, and application of Islamic law (Sharia) is subject to it. ${ }^{79}$ Mohammed Mouktakha Mahabbu, a Muslim legal academic ${ }^{80}$ and secretary of the Muslim Lawyers Association of Nigeria, ${ }^{80}$ correctly sums up the legal-constitutional status of Sharia in Nigeria thus:

This [Nigeria] is not a [true] Islamic state... Some states of the Federation are practicing some aspect of Sharia. [However] it is the Constitution that is governing the affairs and the activities of the Federation [of Nigeria] as well as the state governments. It is the Constitution that is [the ultimate determining legal document], not Sharia itself. [In contrast], in an ideal Islamic State, it is the whole country that is practicing Sharia law. That is quite different from the situation here in Nigeria. ${ }^{81}$ 
Importantly, there are still many Nigerian Muslims who are unsatisfied with the current legal status of Sharia as encapsulated in the compromise position stated in Nigeria's 1999 Constitution (the 1979 Constitution before it). As one Muslim scholar puts it, 'Islam itself is an unconquerable force which, in spite of all oppositions, subversions and attacks from its enemies everywhere, must express its domineering will and assert its authority over all other systems' ${ }^{82}$ Moreover, they contend that Islam provides a complete Code which cannot be fragmented in Nigeria. ${ }^{83}$ In recent years, this contention found expression in the unconstitutional expansion of Sharia law into the realm of criminal law by some states in the northern part of Nigeria. ${ }^{84}$ As the controversy generated by this unconstitutional act appears to have waned, prevailing Boko Haram attacks and utterances, inter alia, resurrect the debate on Constitutionalism and Islamism. The above-quoted recent statement of the Sultan of Sokoto also seems to lend credence to this position.

\section{BOKO HARAM AND NATIONAL SECURITY: WHAT CAN THE LAW DO?}

Obviously, Boko Haram attacks in Nigeria have produced a state of national insecurity. Presently, the Nigerian Armed Forces, assisted by some volunteer foreign military, are labouring to restore security in the country. However, there is no question that terrorism is not a war only for the Armed Forces of the country to fight; there is certainly a role for governments, individuals, organizations and the law. For present purposes it is proposed to briefly discuss the legal framework for dealing with terrorism in Nigeria and assess how this may help to stem terrorism and insecurity in the country.

In 2011, following criminal activities in parts of the country - especially the terrorist attacks of Boko Haram in the north-eastern parts of the country - the Federal Government enacted the Terrorism (Prevention) Act, $2011^{85}$ (as amended by the Terrorism (Prevention) (Amendment) Act 2013). ${ }^{86}$ The Act makes provisions 'for and about offences relating to conduct carried out or purposes connected with terrorism'. However, it does not define terrorism. Instead, section $3(2)^{87}$ thereof defines 'acts of terrorism' as 'an act which is deliberately done with malice aforethought' and which:

1. May seriously harm or damage a country or an international organization; Is intended or can reasonably be regarded as having been intended to (among others) - seriously intimidate a population; seriously destabilize or destroy the fundamental political, constitutional, economic or social structures of a country; and

2. Involves or causes, as the case may be (among others) - an attack upon a person's life which may cause serious bodily harm or death; kidnapping of a person; destruction of a government or public facility, a transport system, a public place or private property likely to endanger human life; the manufacture, possession, acquisition, supply or use of weapons or explosives without lawful authority; or the causing of explosions, the effect of which is to endanger human life.

In furtherance of its purpose, this law prohibits 'all acts of terrorism and financing of terrorism'. ${ }^{88}$ Moreover, it provides for the proscription of an organization formed for the purpose of or which 'engages in participating or collaborating in an act of terrorism or promoting or exhorting others to commit an act of terrorism'. 89 The order of proscription can be made by a judge in Chambers on the application of the Attorney-General of the Federation, National Security Adviser or the InspectorGeneral of Police on the approval of the President. Such order is to be published in official gazette. Thereafter, any person who belongs to or professes to belong to a proscribed organization commits an office under this law and may be liable on conviction to imprisonment for a term of 20 years. 
Ebeku, K. S. A. (2020). Boko Haram and Nigeria's National Security: Some Reflections from Historical-Constitutional Perspective. Advances in Social Sciences Research Journal, 7(5). 503-521.

Furthermore, the law prohibits terrorist meeting; ${ }^{90}$ soliciting and giving support to terrorist groups; ${ }^{91}$ harbouring of terrorists or hindering the arrest of a terrorist; ${ }^{92}$ provision of training and instruction to terrorist groups or terrorists; ${ }^{93}$ failure to disclose information that could lead to the prevention of commission of an act of terrorism or arrest, prosecution or conviction of a suspect; ${ }^{94}$ provision of devices such as explosives or other lethal device to a terrorist or terrorist group; ${ }^{95}$ hostage taking; ${ }^{96}$ terrorist funding, ${ }^{97}$ among others. A person found guilty of any of these offences may be liable on conviction to imprisonment which range between 10 to 20 years. However, any person who provides facilities such as building, vessel or recording device in support of terrorist acts is liable on conviction to life imprisonment. ${ }^{98}$

As it stands, the anti-terrorism law is not perfect - it lacks some pungent provisions that could assist law enforcement personnel in the prevention of terrorist acts. For example, there ought to be a provision for preventive detention in accordance with section 35(1)(c) of the 1999 Constitution of Nigeria. By this provision, a person may be deprived of his personal liberty in accordance with a procedure permitted by law 'to such extent as may be reasonably necessary to prevent his committing a criminal offence'. ${ }^{99}$ With such provision security personnel would be assisted to prevent the commission of terrorist acts by holding some suspects in preventive detention. Moreover, a special Military Tribunal equipped with special trial procedure that would not violate the Constitution should have been established to try terrorists at a special location. The importance of this lies in the fact that it will remove such cases from endemic delay that characterize our regular courts and also help to shield witnesses.

Notwithstanding its shortcomings, the provisions of the extant law could still be of some help in the fight against terrorism if applied pragmatically. From the foregoing, it is clear that the various Boko Haram attacks qualify as acts of terrorism, as defined by the law and clearly violate various substantive provisions of the Terrorism (Prevention) Act 2011 (as amended) as outlined above. Furthermore, the federal government has proscribed the organization ${ }^{100}$ in accordance with the law. ${ }^{101}$ However, while there have been a number of arrests of suspected members of Boko Haram there is no evidence of any serious prosecution let alone conviction of persons as terrorists. Instead, a high profile suspect had managed to escape from custody. In this situation, the law has not yet really been of any assistance in the war against Boko Haram - a metaphor for terrorism in Nigeria. In any case, as earlier mentioned, the law has a good potential to help in the fight against terrorism. Courts of law do not act suo motu; their jurisdiction must be properly invoked by the appropriate officers of the law under the criminal justice system (or by parties in a civil dispute). Presently, it seems the government has been slow in invoking the justice system in the hope that the activities of the organization will fizzle out, and perhaps due to some mundane political considerations. ${ }^{102}$ This thinking cannot make any sense now (not that it ever made any sense) and it is hoped that the potent weapon of the law will now be deployed to assist in the war against terrorism.

Yet, to be successful, judges must be bold, courageous and proactive; ready to abandon or at least modify traditional approaches to criminal trials. This is presently not the case. A recent ruling of a Federal High Court judge will illustrate this point. On June 4, 2014 Gabriel Kolawole J., sitting in an Abuja Federal High Court, refused an application of a Federal prosecuting counsel to shield witnesses in the trial of Boko Haram members accused of terrorism. ${ }^{103}$ The prosecution made the application in order to protect the witnesses from possible Boko Haram attack. The judge had previously ruled to allow the witnesses to be partially shielded when giving evidence but some of 
the witnesses refused to enter the witness box unless allowed to completely cover their face, and this necessitated a fresh application which the judge refused and rejected as lacking merit. In dismissing the application, he stated: 'This court does not have the powers to vacate its earlier ruling. Acceding to such would amount to having empty benches in the court room without the public in attendance'. It appears the fresh application required the court to be cleared.

With respect, while the ruling was in line with the traditional adversarial approach of orality and public hearing it ignores the risky nature of giving evidence against a Boko Haram suspect or accused. The natural consequence of this is that witnesses will be unwilling to give evidence in terrorism cases involving Boko Haram and a terrorist on trial will walk out of the court a free man. Surely this approach does not speak well of the law and must not be allowed to thrive. Otherwise the law may be unhelpful in the fight against terrorism and the desire to restore national security. If this be the case Chief (Dr) Nabo Graham-Douglas, who believed that the law should respond to circumstances and the social milieu, ${ }^{104}$ would not be amused. No serious lawyer would indeed be abused. Certainly not me.

\section{CONCLUDING REMARKS}

Frequent and increasing Boko Haram attacks in northern Nigerian clearly tantamount to terrorism as understood in contemporary times the world over. ${ }^{105}$ The ruthless actions which result in the loss of human lives must be condemned as unmitigated acts of wickedness and arguably qualify as crimes against humanity. Unsurprisingly, national security has degenerated as a resulted of the unrelenting terrorist attacks.

From an historical and constitutional perspective this paper examined the motive behind the terrorist attacks and has shown that religious and political reasons lay behind the attacks. From a religious angle, the terrorists seek to Islamize Nigeria and this ambition can be traced to Nigeria's pre-colonial, colonial and post-colonial history. From the post-colonial era to-date it is essentially a struggle for the supremacy of Sharia over Nigeria's Constitution.

Given the unrelenting terrorist attacks in Nigeria, the paper also examined the legal framework for the prevention of terrorism in the country. It was found that so far the law has not assisted in the fight against terrorism on account of political considerations and tenacious insistence of judges to stick to traditional approaches to criminal hearing. In the end, it is recommended that the law should respond to the prevailing circumstances as suggested above in order to remain relevant to society.

\section{Postscript}

This paper was originally written and presented in 2014 at a public lecture. Six years afterwards, its content rings true as though it has been written in the year 2020. This was the impetus that led me to seek to publish it for the first time. It is a notorious fact that Boko Haram is still a security concern to Nigeria and neighbouring countries such as the Republic of Chad, Niger Republic, and the Republic of Cameroun, despite claims of military defeat of the insurgents.

In a paper published in 2018, this author quoted the inaugural speech of President Buhari shortly after his inauguration on 29 May 2015, where he said on the issue of security: ${ }^{106}$ 
Ebeku, K. S. A. (2020). Boko Haram and Nigeria's National Security: Some Reflections from Historical-Constitutional Perspective. Advances in Social Sciences Research Journal, 7(5). 503-521.

The most immediate is Boko Haram's insurgency... But we cannot claim to have defeated Boko Haram without rescuing the Chibok girls and all other innocent persons held hostage by insurgents... This government will do all it can to rescue them alive... Boko Haram became a terrifying force taking tens of thousands of lives and capturing several towns and villages covering swathes of Nigerian sovereign territory... For now, the Armed Forces will be fully charged with prosecuting the fight against Boko haram. We shall overhaul the rules of engagement to avoid human rights violations in operations ${ }^{107}$

The Chibok girls, numbering 276, were kidnapped from their secondary school hostel in the town of Chibok in Borno State, Nigeria in April 2014. More than six years after the attack, over 112 of the girls are still missing under the watch of President Buhari, who is presently serving a second term in office as of May 2020. Hence, in the words of President Buhari, Nigeria in 2020 'cannot claim to have defeated Boko Haram'. In fact, since 2009 Boko Haram attacks have not ceased in Nigeria. A more recent variant is Fulani herdsmen attacks. ${ }^{108}$

\section{References}

1. The official name of the group is 'People Committed to the propagation of the Prophet's Teachings and Jihad'.

2. Sarah Boseley, 'Iraq Suicide Bomb Toll Revealed' (The Guardian, Friday 2 September 2011); available online at < http://www.theguardian.com/world/2011/sep/02/iraq-suicide-bomb-toll-revealed> (accessed 31 May 2014).

3. See 'Fear mars Sunday worship in Kano' (29 January 2012) Vanguard (Lagos) < http://www.vanguardng.com/2012/01/fear-mars-sunday-worship-in-kano/ > (accessed 7 February 2012).

4. KSA Ebeku, 'Beyond Terrorism: Boko Haram Attacks and national Constitutional Questions in Nigeria' (2011) 15 Calabar Law Journal 1-47.

5. Maiduguri is the capital city of Borno state of Nigeria, and is located in the north-eastern part of Nigeria bordering Chad Republic, the Republic of Cameroon and the Republic of Niger. The area is predominated by the Kanuri ethnic group.

6. 'Nigeria policemen in court trial for Boko Haram' (13 July 2011) BBC News (London); < http://www.bbc.com/news/world-africa-14136185> (accessed 11 June 2014). The Arabic/Islamic word 'Jihad' translates into English as 'a Muslim holy war or spiritual struggle against infidels [i.e. non-Muslims]'.

7. 'Boko' is Hausa for 'Western education', while 'Haram' comes from Arabic literally meaning 'forbidden' and figuratively meaning 'sin'. The sect considers the name 'Boko Haram' as derogatory.

8. Note that Boko Haram is also widely regarded as an Islamic sect because it ideologically disagrees with other Muslims in some aspects of the Muslim religion.

9. Farouk Chothia, 'Who are Nigeria's Boko Haram Islamists?' (11 January 2012) BBC News Africa (London) < http://www.bbc.co.uk/news/world-africa-13809501> (accessed 11 June 2014).

10. Ibid.

11. The Koran is the sacred religious book of Muslims.

12. Chothia (note 9 above). As a collection of revelations from God, Sharia is regarded as immutable laws. Unlike man-made legislation, Muslims hold that no man can ever change or amend the laws of God.

13. See, by example, Chinelo Obogo, 'Politics, religion, deaths and Boko Haram' (18 January 2012) The Sun (Lagos); < http://archive2.sunnewsonline.com/webpages/politics/2012/jan/18/politics-18-01-2012-001.htmll> (last accessed 11 June 2014). See also Chothia (note 9 above).

14. For example, see Chothia (note 9 above). 
15. Obogo (note 13 above). Some evidence suggests that contrary to Police claims, Mohammed Yusuf was captured alive and extra-judicially executed by the Police.

16. ibid. See also Chothia (note 9 above).

17. Obinna Nwodim, 'Anikpo Outlines Panacea to Insecurity Upsurge in Nigeria' (Uniport Weekly, Vol. 18, No. 7 April 28 - May 5, 2014), 4.

18. Ibid.

19. Ibid.

20. See, for example, Chothia (note 9 above).

21. The organization hardly indulges in issuing statements, apart from claiming or denying responsibility for terrorist acts.

22. He succeeded Mohammed Yusuf in 2009 as leader after the latter was killed by the Police.

23. The video was made in the local Hausa language (hereafter, Boko Haram video). The English translation stated in the text here can be found at: <http://saharareporters.com/video/video-boko-haram-leader-imam-abubakarshekau-message-president-jonathan> (accessed 11 June 2014). See also 'Boko Haram leader appears in video' (12 January 2012) Thisday (Lagos); <http://www.thisdaylive.com/articles/boko-haram-leader-appears-invideo/106946/> (accessed 14 June 2014).

24. Boko Haram video (note 23 above).

25. ibid.

26. Madalla is actually located in Niger State of Nigeria which bothers Nigeria's Federal capital Territory Abuja.

27. Shiv Malik, 'Nigerian churches targeted by Christmas day bombs' (25 December 2011) Guardian (Lagos); <http://www.guardian.co.uk/world/2011/dec/25/nigerian-church-bombed-christmas-prayers> (accessed 11 June 2014).

28. Martin Plaut, 'Nigerian churches hit by blasts during Christmas prayers' (25 December 2011) BBC News Africa (London); <http://www.bbc.co.uk/news/world-africa-16328940 > (accessed 11 June 2014).

29. Local Christians (especially those in the northern states of Nigeria) say in interviews that what has been reported in various news media regarding attacks on Christians and Churches is only a tip of the iceberg.

30. See 'Nigerian Church shootings kill six' (6 January 2012) Guardian (Lagos); <http://www.guardian.co.uk/world/2012/jan/06/nigerian-church-shootings> (last accessed 5 March 2012).

31. Umar Yusuf, 'Boko Haram attack claim 12 in Adamawa' (10 January 2012) Vanguard (Lagos); <http://www.vanguardngr.com/2012/01/boko-haram-attack-claims-12-in-adamawa/> (last accessed 5 March 2012).

32. That attack killed 40 persons and injured many persons. See Tony Akowe, 'Easter Sunday suicide bomb kills 40 in Kaduna' (9 April 2012) The Nation (Lagos) < http://www.thenationonlineng.net/2011/index.php/news/42518-easter-sunday-suicide-bomb-kills-40-inkaduna.html> (last accessed 9 April 2012). A further targeted attack occurred on Sunday 29 April 2012 in Bayero University, Kano. The attack was on Catholic students and others attending a Catholic Mass in a lecture Hall in the University. The attack elicited strong reactions from the Christian Association of Nigeria (CAN). See H Ibrahim, 'Terror attacks: Northern CAN gives Jonathan ultimatum' (1 May 2012) Nigerian Tribune (Lagos); < http://tribune.com.ng/index.php/news/40142-terror-attacks-northern-can-gives-jonathan-ultimatum> (last accessed 5 May 2012).

33. See 'US: Nigeria's Islamic Militants Are Capitalizing on Popular Discontent' (11 April 2012) Sahara Reporters Online; < http://saharareporters.com/news-page/us-nigerias-islamic-militants-are-capitalizing-populardiscontent > (last accessed 15 April 2012). 
Ebeku, K. S. A. (2020). Boko Haram and Nigeria's National Security: Some Reflections from Historical-Constitutional Perspective. Advances in Social Sciences Research Journal, 7(5). 503-521.

34. See 'Fear mars Sunday worship in Kano' (29 January 2012) Vanguard (Lagos); <http://www.vanguardngr.com/2012/01/fear-mars-sunday-worship-in-kano/ > (last accessed 14 February 2012).

35. ibid.

36. ibid

37. Isolated attacks on Mosques by Boko Haram do not detract from this conclusion. The organization has made clear that it will attack any Muslim who criticises them and that praying in a Mosque will not prevent such attack. It is likely that any such attack is but a furtherance of that decision.

38. Remi Adekoya, 'Nigeria's Islamists have the government dancing to their tune' Guardian (Lagos, 4 January 2012) <http://www.guardian.co.uk/commentisfree/2012/jan/04/nigeria-islamists-boko-haram> accessed 5 March 2012. See also ‘Boko Haram Orders Christians Out of Northern Nigeria, Threatens Army' (3 January 2012) Nigeria Masterweb Daily News (Lagos) <http://nigeriamasterweb.com/blog/index.php/2012/01/03/bokoharam-orders-christians-out-of-northern-nigeria-threatens-army> (last accessed 5 March 2012).

39. For more information, see Ebeku (note 4 above).

40. Sulaiman (note 40 above) 69.

41. ibid.

42. ibid.

43. ibid 53-54.

44. ibid 57.

45. ibid 70-71.

46. Between January and April 2012 Boko Haram attacked and destroyed a total of ten primary and secondary schools following Western education. See Musa Ndjavara, 'Gunmen Touch Two Schools In Borno' (15 April 2012) The Guardian (Lagos); < http://www.ngrguardiannews.com/index.php?option=com_content\&view=article\&id=83338:gunmen-torchtwo-schools-in-borno-\&catid=1:national\&Itemid=559> (last accessed 15 April 2012). Although no University has been attacked as at April 2012, the sect has declared its plan to attack Universities (some of which it named).

47. For example, the Christian Association of Nigeria (CAN) often made the suggestion in various statements and interviews.

48. See Obogo (note 13 above). Cf. the position of the Sultan of Sokoto during the colonial era. In a letter to the first British High Commissioner of Northern Nigeria, the Sultan of Sokoto had stated: 'As between a Muslim and nonMuslim there can be no dealings except as between Musulmans and Unbelievers - war, as God Almighty has enjoined on us' - quoted in BO Nwabueze, Constitutionalism in the Emergent States (C Hurst, London, 1973) 8485.

49. 'Sultan to govt: address injustice against Muslims', (The Nation, 26/05/14); available online at: <http://thenationonlineng.net/new/sultan-govt-address-injustice-muslims/> (accessed 26/05/14).

50. J Hatch, Nigeria: A History (Secker and Warburg, London 1971) 12. For more information on the birth of Nigeria, see KSA Ebeku, Oil and the Niger Delta People in International Law (Koppe Verlag, Koln 2006) 14-18.

51. Ibid, at 12 .

52. Mohammed Tabi'u, 'Constraints in the application of Islamic Law in Nigeria' in SK Rashid (ed.), Islamic Law in Nigeria (Islamic Publications Bureau, Lagos) 75.

53. Quoted in Femi Ajayi, 'Senators in Dilemma Over Sharia Law', available at: < http://nigeriaworld.com/columnist/ajayi/senators.html> (last accessed 19 April 2012).

54. ibid. 
55. Quoted in I Sulaiman, 'Victor Takes All: The Shariah in Secular Nigeria' in S Khalid (ed.), Shariah, Social Change and Indiscipline in Nigeria (University of Sokoto Press, Sokoto 1987) 55-64, at 60-61.

56. For incisive discussion on the scope of application of Islamic law in Nigeria, see KSA Ebeku, 'The Limited Applicability of Sharı̄'ah under the Constitution of Nigeria' in R Grote and T Röder (eds), Constitutionalism in Islamic Countries: Between Upheaval and Continuity (OUP 2011) 73-92.

57. Chief Rotimi Williams was an eminent Nigerian lawyer and chairman of the Constitution Drafting Committee (CDC) of the mid-1970s which produced a draft constitution that later became the Constitution of Nigeria 1979.

58. The CDC had included a Federal Sharia Court of Appeal (to be presided over by a Grand Mufti) in the Draft Constitution, after heated debates, but this was rejected in the Constituent Assembly (CA). See AA Oba, 'Islamic Law as Customary Law: The Changing Perspective in Nigeria' (2002) 51 ICLQ 840. On the recommendation and inclusion of the Federal Sharia Court of Appeal in the Draft Constitution, see Report of the Constitution Drafting Committee, Vol. II (Federal Ministry of Information, Lagos 1976) 110 and 113. And for an interesting account of the Sharia debate in the CA, see Udo Udoma, History and the Law of the Constitution of Nigeria (Malthouse Press Ltd, Lagos 1994) 313.

59. The text of Rotimi's argument was published in the New Nigerian newspaper of 4 November 1977; Quoted in I Sulaiman, 'Victor Takes All: The Shariah in Secular Nigeria' in S Khalid (ed.), Shariah, Social Change and Indiscipline in Nigeria (University of Sokoto Press, Sokoto 1987) 55-64, at 59.

60. IKR Sulaiman, 'The Shariah and the 1979 Constitution' in S Khalid Rashid (ed.) (note 28 above) at 53.

61. Sulaiman (note 28 above) at 62 . Note that IKR Sulaiman and I Sulaiman is the same person using inconsistent initials.

62. ibid.

63. ibid.

64. 'Sultan to govt: address injustice against Muslims', (The Nation, 26/05/14); available online at: $<$ http://thenationonlineng.net/new/sultan-govt-address-injustice-muslims/> (accessed 26/05/14).

65. Note that references in this article to constitutional provisions refer to the current Constitution of 1999, except where otherwise stated.

66. For example, in the USA and Australia apart from the central constitution of the country the constituent states of the federation have their respective state constitution. The same is true in Canada and Germany.

67. This contrasts with the position during the First Republic in Nigeria (1963-1966), when the four constituent regions had their respective regional constitution, separate and distinct from the Constitution of Nigeria 1963. The current position is probably the result of the uniqueness of the Nigerian federation - formed not by erstwhile existing sovereign states as is the case in other federations but by states created from time to time by local authorities. Furthermore, the situation might have been informed by the need to foster national unity or nationalism given the way the British colonialists forcefully brought erstwhile disparate nations into one nation. This is also one of the reasons that explain the existence of only one national Police Force in the country.

68. It is a sad commentary to note that since independence in 1960 Nigeria has not had a hitch-free and successful census exercise. Every census exercise conducted ever since, including the latest one in 2006, had been steeped in controversy and remain inconclusive.

69. This is a notorious contention in most northern states of Nigeria. For a specific claim that 'Muslims constitute a majority of the Nigerian population', see SK Rashid, 'Introduction' in SK Rashid (ed.), Islamic Law in Nigeria (Islamic Publications Bureau, Lagos) 1, 4.

70. An opportunity to investigate and settle this issue was missed at Nigeria's 2006 census exercise. Given the longstanding claims of Muslims that they constitute a majority in the country, the leadership of the Christian Association of Nigeria (CAN) seriously demanded that a question on religious affiliation be included in the census questions, but the federal government refused to do this - probably because of the volatile nature of the issue and the seeming objection of Nigerian Muslims. Although the census was inconclusive it might well have provided some important information. 
Ebeku, K. S. A. (2020). Boko Haram and Nigeria's National Security: Some Reflections from Historical-Constitutional Perspective. Advances in Social Sciences Research Journal, 7(5). 503-521.

71. Cf. AW Bradley and KD Ewing, Constitutional and Administrative Law, (14th ed., Pearson 2007) 8.

72. The Constitution was ratified on 4 January 2004 by a 500 -member loyah jirgah (or grand council of representatives from across the country). See 'A New Constitution for Afghanistan' (26 January 2004) CBS News (New York) <http://www.cbsnews.com/stories/2004/01/02/world/main591116.shtml> last accessed 14 April 2009. The full text of the Constitution can be found online at: < http://www.afghanweb.com/politics/current_constitution.html> last accessed 6 April 2010.

73. Afghan Constitution Chapter 10, Article 1 provides: 'The provisions of adherence to the fundamentals of the sacred religion of Islam and the regime of the Islamic Republic cannot be amended'.

74. See AA Oba, 'Islamic Law as Customary Law: The Changing Perspective in Nigeria' (2002) 51 ICLQ 840.

75. Constitution of Nigeria 1999, section 1. In fact, the position of Nigerian law is that Islamic law is a species of customary law. See Area Courts Edict 1967, section 20 (re-enacting the provisions of the Northern Nigeria Native Courts Law 1956 with some modifications).

76. Constitution of Nigeria 1999, section 10.

77. See, for example, Constitution of Nigeria 1999, section 277. For incisive discussion on the scope of application of Islamic law in Nigeria, see KSA Ebeku, 'The Limited Applicability of Sharī'ah under the Constitution of Nigeria' in R Grote and T Röder (eds), Constitutionalism in Islamic Countries: Between Upheaval and Continuity (OUP 2011) 73-92.

78. Ultimate appeals would still lie to a secular Court of Appeal and the Nigerian Supreme Court (final court of appeal).

79. Section 1 of the Constitution proclaims the supremacy of the Constitution thus: 'This Constitution is supreme and its provisions shall have binding force on all authorities and persons throughout the Federal Republic of Nigeria'. Under section 1(3) the Constitution categorically states that 'If any other law is inconsistent with the provisions of this Constitution, this Constitution shall prevail and the other law shall to the extent of the inconsistency be void".

80. He is a law lecturer at Kano State Polytechnic, Kano State, Nigeria.

81. Kano state Chapter.

82. Isiyaku Ahmed, 'Northern Nigeria's Islamic Laws Seen by Some to be Moderating' (14 April 2007) VOA News (New York); <http://www.voanews.com/english/news/a-13-2007-04-14-voa31.html> (last accessed 12 February 2012).

83. IKR Sulaiman, 'The Shariah and the 1979 Constitution' in S Khalid Rashid (ed.) (note 26 above) 53.

84. ibid, esp. at 55.

85. See KSA Ebeku, 'Constitutional and Human Rights Issues in the Implementation of Islamic Law in the Northern States of Nigeria' (2004) 7/2 Recht in Africa 155-176.

86. Act No. 10, 2011.

87. Hereafter, Terrorism (Prevention) Act 2011 (as amended).

88. Renumbered by the 2013 amendment Act.

89. Terrorism (Prevention) Act 2011 (as amended), section 1. This is a new section 1 inserted by the 2013 amendment Act (amending section 1 of the Principal Act).

90. Terrorism (Prevention) Act 2011 (as amended), section 2.

91. Terrorism (Prevention) Act 2011 (as amended), section 4.

92. Terrorism (Prevention) Act 2011 (as amended), section 5.

93. Terrorism (Prevention) Act 2011 (as amended), section 6.

94. Terrorism (Prevention) Act 2011 (as amended), section 7. 
95. Terrorism (Prevention) Act 2011 (as amended), section 8.

96. Terrorism (Prevention) Act 2011 (as amended), section 9.

97. Terrorism (Prevention) Act 2011 (as amended), section 15.

98. Terrorism (Prevention) Act 2011 (as amended), section 13.

99. Terrorism (Prevention) Act 2011 (as amended), section 12.

100. See generally, K.S.A. Ebeku, 'Constitutional Guarantee of Personal Liberty and Preventive Detention in Nigerian Law' (1995) 7(3) African Journal of International and Comparative Law 620-648.

101. See 'Jonathan bans Boko Haram, Ansaru' (Vanguard, June 5, 2013); available at: < http://www.vanguardngr.com/2013/06/jonathan-bans-boko-haram-ansaru/> (accessed June 6, 2014).

102. The proscription order was gazetted as the Terrorism (Prevention, Proscription Order) Notice 2013. Some foreign countries, such as the USA, as well as the United Nations have also listed Boko Haram as a terrorist organization.

103. F. Soriwei and A. Adepegba, 'FG yet to prosecute 500 Boko Haram suspects' (Punch, January 26, 2014); available at: < http://www.punchng.com/news/fg-yet-to-prosecute-500-boko-haram-suspects/ > (accessed June 9, 2014).

104. See 'Court refuses FG's application to reverse ruling in Boko Haram suspects' (DailyPost, June 4, 2014); available at: < http://dailypost.ng/2014/06/04/court-refuses-fgs-application-reverse-ruling-boko-haram-suspects-trial/ $>$ (accessed June 9, 2014).

105. The Supreme Court decision in Awolowo v Shagari was much criticized but he justified it on the basis that had it been the contrary the military may not have returned power to civilians as the country very much expected.

106. H Ibrahim, 'UN declares Boko Haram Terror Group' (26 January 2012) Nigerian Tribune (Lagos); < http://tribune.com.ng/index.php/front-page-news/35023-un-declares-boko-haram-terror-group-urgesjonathan-to-fight-sect-with-full-force-show-yourselves-jonathan-challenges-boko-haram-members-britainoffers-to-assist-nigeria> (last accessed 1 May 2012). See also Nigeria's Terrorism (Prevention) Act 2011, ss.1 and 2.

107. K.S.A. Ebeku, 'Legal Implications of Recurrent Mass Killings in Nigeria by Fulani Herdsmen' (2018) 6(2) Journal of Law and Criminal Justice 44-61, at 51.

108. K.S.A. Ebeku, 'Fulani Herdsmen Attacks in Nigeria: A Case of Genocide in the Making' (2019) 3(6) International Journal of Law, Humanities \& Social Science 62-84. See also S.A. Olofinbiyi, 'On the Trajectory of Boko Haram Terrorism in Nigeria: Socio-Economic Challenges and Intervention Strategies for Conflict Resolution' (2019) 2(3) Asian Journal of Interdisciplinary Research 76-96. 